\title{
Türkiye'nin Bitkisel Biyolojik Çeşitliliğinin Korunması ve Sürdürülebilir Kullanımına İlişkin Sorunlar ve Çözüm Önerileri
}

\author{
*Alptekin KARAGÖZ1,$\quad$ Kürşad ÖZBEK², Nurgül SARI ${ }^{2}$ \\ ${ }^{1}$ Aksaray Üniversitesi, Aksaray Teknik Bilimler Meslek Yüksekokulu, Aksaray \\ ${ }^{2}$ Tarla Bitkileri Merkez Araştırma Enstitüsü Müdürlüğü, Ankara \\ *Sorumlu yazar e-posta (Corresponding author e-mail): akaragoz@aksaray.edu.tr \\ Geliş Tarihi (Received): 05.04.2016 Kabul Tarihi (Accepted): 26.05.2016
}

\section{Öz}

Bu çalışma Türkiye'de bitkisel biyolojik çeşitliliğin uzmanlarca öngörülen sorunları ve çözüm yollarının belirlenmesi amacılla yapılmıştır. Çalışma, Ankara'da Mayıs ve Eylül 2015 tarihlerinde 2 kez düzenlenen toplantılara katılan toplam 120 civarındaki katılımcının görüş ve düşünceleri alınarak belirlenen sorunlar ve bu sorunların her biri için çözüm önerileri içeren listelerdeki faktörlerin, Analitik Hiyerarşi Proses (AHP) istatistik yöntemiyle öncelik verilmesi şeklinde yapılmıştır. Çalışma sonunda katıımcılarca öncelik verilen sorunlar ve bunların çözümü için belirlenen önlem ve faaliyetlerden en önemlileri sıralanmışır. Belirlenen sorunların ilk beşi şunlardır: Arazi bozulması, yasal düzenlemelerin / yaptıımların yetersizliği, plan ve programlarla ilgili sorunlar, doğadan aşırı bitki hasadı, kapasite ve yetişmiş insan eksikliği. Bu sorunlardan "arazi bozulmasına" karşı, alanların, amacı dışında kullanımını önleyecek yasal düzenlemelerin yapılması; yatııımlarda biyolojik çeşitliliğin dikkate alınması gibi hususlar ön plana çıkmışıı. "Yasal mevzuatla" ilgili sorunların giderilmesinde; araştırma izinleri yerine sürekli yetkiyi belgeleyen kart verilmesi, toplama izinlerinde yerli araştırmacı lehine düzenlemeler yapılması istenmiştir. "Plan ve programlarla" ilgili olarak; plan ve projelerin Ulusal Biyoçeşitlilik Stratejisi ve Eylem Planı'na (UBSEP) uygun olması; plan ve projelerde kaynakların etkin kullanılması önerileri geliştirilmiştir. "Doğadan aşıı toplama" sorununa karşı; soğanlı bitkiler dışında da toplama kotaları listesi hazırlanması ve doğadan toplanan türlerde kültüre alma çalışmaları yapılması önerilmiştir. "Kurumsal kapasitelerimizin" eksikliklerinin giderilmesi konusunda da; kurumlar arası iş birliği yapılması; BGK araştırma enstitülerinin kurulması gündeme getirilmiştir.

Anahtar Kelimeler: Türkiye, bitkisel biyoçeşitlilik, sorunlar, çözüm önerileri, AHP

\section{Problems Regarding Conservation and Sustainable Use of Turkey's Plant Biodiversity and Proposed Solutions}

\begin{abstract}
Aim of this research was to determine the challenges and solutions to the existing problems of plant genetic resources in Turkey. For this purpose, 2 days meetings were organized in Ankara twice, with participation of total 120 experts. Expert opinions on challenges and likely solutions were identified and the listed matters were analysed by means of Analytic Hierarchy Process to determine the magnitude of each factor on the problems and the solutions. As a result, most important problems and likely solutions were listed with priority rankings. First five prior problems were listed as the following; land degradation, inadequacy of legislative arrangements; lack of proper planning; over harvesting from nature; and lack of capacities. Suggested remedies for "land degradation" were enacting legislation against misuse of lands and the consideration of biodiversity in investments. Regarding the "legislative arrangements", priority was given to research permits given by the government bodies. The researchers demand "researcher's identity cards" to replace research permits that are given by several government bodies, and they wish to have legal arrangements, in favour of local researchers for collecting activities. Regarding the "environmental planning", they wish the plans to be in harmony with National Biodiversity Strategy and Action Plan, and effective use of resources. Concerning "over harvesting from nature", the experts offered widespread quota application on plants similar to that of for bulb plants, and field cultivation of wild plants. Regarding "institutional capacity gaps", the experts recommend strong collaboration between institutions, and establishment of a Plant Genetic Resources Institute.
\end{abstract}

Keywords: Turkey, plant biodiversity, challenges, remedies, AHP 


\section{Giriş}

Ü Ikemiz, bitkisel biyolojik çeşitlilik bakımından Avrupa kıtasıyla kıyaslanacak kadar zengin olup, bu zenginliğin korunması ve sürdürülebilir kullanımı için geçmişten günümüze değin altyapı oluşturma/geliştirme, araştırma, ilgili yasal düzenlemeler, eleman ve bütçe tahsisi gibi konularda bölgesinde lider konumundadır.

Günümüzde Gıda, Tarım ve Hayvancılık Bakanlığı bünyesinde, biri Ankara'da Tarla Bitkileri Merkez Araştırma Enstitüsü Biyolojik Çeşitlilik Genetik Kaynaklar Bölümündeki Türkiye Tohum Gen Bankası, diğeri de İzmir'de Ege Tarımsal Araştırma Enstitüsü'nde yer alan Ulusal Gen Bankası olmak üzere iki adet gen bankası faaliyet göstermektedir.

Ex-situ koruma kapsamında yöntemler çeşitlenmektedir. Bakanlık tarafından özellikle uygulanan koruma yöntemleri; botanik bahçeleri ve tohum ve arazi gen bankalarıdır. Tarımsal Araştırmalar ve Politikalar Genel Müdürlügü'ne (TAGEM) bağıı iki Tohum Gen Bankasında muhafaza edilmekte olan materyal sayısı şöyledir: Ankara'daki Tarla Bitkileri Merkez Araştırma Enstitüsü'ne (TARM) bağlı Türkiye Tohum Gen Bankasında 463 türe ait 63.269 örnek; İzmir'deki Ege Tarımsal Araştırma Enstitüsü (ETAE) gen bankasında 3.244 türe ait 57.726 örnek olmak üzere her iki gen bankasında toplam 120.995 örnek saklanmaktadır. Aynı zamanda TAGEM önderliğinde TARM ve ETAE işbirliği ile "Dijital Herbaryum" faaliyete geçmiştir (http://herbaryum.tagem.gov.tr/).

Tarımsal biyolojik çeşitlilik ulusal sorumlusu olan Ege Tarımsal Araştırma Enstitüsü, Genetik kaynaklar veri tabanı oluşturulması programı kapsamında çatı proje altında "Bitki Genetik Kaynaklarının Dokümantasyonu" projesini yürütmektedir.

Bitki Genetik Kaynaklarının (BGK) survey / toplama, üretim / yenileme, muhafaza, karakterizasyon ve değerlendirme çalışmalarına ait bilgilerin derlenmesi, işlenmesi, saklanması amacıyla BGK konusunda yürütülen çalışma ve araştırmalardan elde edilen veriler standart olarak kaydedilmektedir.

TAGEM'e bağlı 17 Araşşırma Enstitüsünde bulunan Arazi Gen Bankalarında 162 türe ait 18.490 materyal (meyve ve asma, süs bitkisi, geofit gibi tüm vegetatif materyal) muhafaza edilmektedir. Ege Tarımsal Araştırma Enstitüsü sorumluluğundaki meyve türleri veri tabanında ise 115 türe ait 8.121 adet materyal bilgisi kayıtlıdır.

Ülkemizde biyoçeşitliliğin durumu, mevcut ve olası riskler ve alınması gereken önlemler üzerine birçok çalışma yapılmıştır. Karagöz ve ark. (2010) Türkiye'de biyolojik çeşitliliği en fazla tehdit eden faktörler olarak tarımsal çalışmalar (mera alanlarının sürülmesi, aşırı otlatma, anızın yakılması, aşırı gübre ve tarımsal ilaç kullanımı, yüksek verimli çeşitlerin çifţi çeşitlerinin yerini alması), şehirleşme, endüstrileşme, yol ve baraj yapımları, doğadan aşırı bitki toplama ve sökümü, aşırı orman kesimi ve orman yangınları, ikinci konut edinimi, turizm sektöründeki hızlı gelişmeler ve yetişmiş insan eksikliği gibi faktörleri sıralamışlardır.

Ülkemiz biyolojik çeşitlilikle ilgili çok sayıda uluslararası anlaşma, antlaşma ve sözleşmelere taraftır. Ayrıca koruma ve sürdürülebilir kullanım konusunda her düzeyde yasal düzenlemeler de zamanı içinde yapılmıştır. Ancak, taraf olduğumuz uluslararası düzenlemeler de dâhil olmak üzere, değişen ülke ve dünya koşulları göz önüne alındığında koruma ve sürdürülebilir kullanım konusunda ülkemizin bulunduğu durumun belirli dönemlerde gözden geçirilmesi, güncellenmesine gerek duyulan yasal düzenlemeler varsa bunların da günün koşullarına uydurulmasına gerek vardır.

Türkiye'de bitki genetik kaynaklarının toplanması ve değerlendirilmesi konusunda çalışmalar XX. Yüzyılın ilk çeyreğinde başlamıştır. Türk bilim adamı Mirza Gökgöl, Dünya'da genetik kaynakların öneminin henüz anlaşılmaya başlandığı dönemlerde, bu konuda söz sahibi olan Vavilov, Harlan ve Zhukovsky gibi ilim adamları ile eş zamanlı olarak, Türkiye'nin her yanından topladığı binlerce buğday örneklerini karakterize ederek 18.000 'in üzerinde farklı tip ve bunların arasından da 256 adet yeni buğday varyetesi belirlemiştir. Gökgöl, "Türkiye'de bulunan çiftçi çeşitlerinin, bitki ıslahçıları için sonsuz bir hazine" olduğunu belirtmiştir (Gökgöl 1935; 1939; Gökgöl ve Taşan 1978).

Güner ve ark. (2012) Türkiye'de her 10 günde yeni bir bitki türü belirlendiğinden bahisle florada 3.649 tanesi endemik olmak üzere toplam 11.707 bitki taksonu olduğunu bildirmektedir.

2010 Ekim ayında Japonya'nın Nagoya kentinde gerçekleştirilen BM Biyolojik Çeşitlilik 
Sözleşmesi (BÇS) 10. Taraflar Konferansı'nda 2011-2020 yılları arası Uluslararası Biyolojik Çeşitlilik Onyılı olarak ilan edilmiştir. Toplantıda 2020 yılına kadar dünyada biyolojik çeşitlilik kaybının durdurulması temel amacıyla Biyoçeşitlilik Stratejik Planı ve kısaca "Aichi Hedefleri" olarak anılan 2020 Biyoçeşitlilik Hedefleri kabul edilmiştir (Anonim, 2016b). Aichi hedefleri toplam 5 stratejik amaç ve 20 hedeften oluşmaktadır.

Young et al. (2005) insan kaynaklı etmenlerle biyoçeşitlilik muhafaza çalışmaları arasındaki çatışmanın tüm Avrupa ekosistemlerinde giderek artan bir şekilde devam ettiğini; bildirerek 3 konunun altını çizmişlerdir. Bunlar; "tarımsal ve silvikültürel faaliyetlerin yoğunlaşması veya arazilerin terk edilmesi", "rekreaksyonel kullanım ve avcılık faaliyetleri" ve "politikayla bağlantılı tehditler" olarak sıralanmıştır. Çatışmaların önlenmesinde ilk adım olarak da sorunlar çıkmadan önce bunları oluşturan sebeplerin ortadan kaldıııması önerilmekte, bu açıdan da etkilenen habitatlar ve türlerin intiyaçları konusunda artan bir farkındalık oluşturmanın ardından, çatışmaların sosyal ve kültürel boyutuna çözüm getirecek yönetim planlarının devreye sokulması önerilmektedir.

Henle et al. (2008) Avrupa'nın tarım yapılan alanlarında biyoçeşitliliğin giderek azalmakta olduğunu, bunun en büyük nedenlerinin ise yoğun tarım uygulamaları, bir zamanlar verimsiz olup şimdilerde terk edilmiş durumda olan Yüksek Doğa Değerlikli Çiftlikler ve son olarak da tarımsal işlemlerin boyutunda meydana gelen değişimler olduğunu bildirmektedir.

Maes et al. (2012) Avrupa Birliği'nde biyoçeşitliliğin muhafazasının habitat ve türler bazında ele alındığını, korunan alanlar oluşturma çalışmalarının 92/43/ECC kodlu Habitat Direktifi doğrultusunda gerçekleştirildiğini bildirmektedir. Biyolojik çeşitliliğin muhafazasının aynı zamanda ekosistem hizmetlerini de destekler nitelikte olmasına karşın, biyoçeşitlilikle bağlantılı olan ekosistem hizmetlerinin Avrupa'da çok geri bir düzeyde değerlendirildiği de ifade edilmektedirler.

Avrupa Çevre Ajansı tarafından yayınlanan bir raporda (Anonim 2015) Avrupa Birliğinde sınırlı sayıda türler ve habitatların, 2020 biyoçeşitlilik hedeflerinde belirtilen uygun koşullarda koruma statüsüne sahip olduğu, bu bakımdan belirlenen hedeflere ulaşılmadığından bahisle, geçmişte Natura 2000 ağı içinde uygun koruma statüsü verilen alanların Avrupa Birliği karasal alanlarının \%18'ini, deniz alanlarının da \%4'ünü başarılı bir şekilde koruma altına aldığını bildirilmektedir. Raporda ayrıca Avrupa Birliği içindeki tehdit altındaki türlerden \% 25'inin yok olma tehlikesine maruz olduğuna işaret edilmektedir.

Hood (2010) dünya biyoçeşitliliğini tehdit eden önemli faktörleri doğal alanların bozularak tarım alanına dönüştürülmesi, ormanların yok edilmesi, iklim değişikliği, doğal kaynakların aşırı tüketimi, kimi alanlara dışarıda yabancı yayılımcı türler getirilmesi olarak sıralamaktadır. Bu faktörlerin etkileri bulunulan coğrafi konuma göre değişmektedir. Hayvan türlerinin kaybının 1600 yılından bu yana \% 39'unun yabancı yayılımcı türlerin istilası, \% 23'ünün aşırı avlanmadan kaynaklandığı ifade edilmiştir. Biyoçeşitlilik kaybının ikincil nedenleri olarak da insan nüfusunun aşırı artışı, aşırı tüketim, aşırı atık üretme, şehirleşme ve uluslararası çatışmalar olduğu bildirilmektedir.

Afrika kıtasında biyoçeşitliliği tehdit eden çok sayıdaki faktörle başa çıkmak için biyoçeşitliliğin ulusal gelişme planlamaları ve politikalarına dâhil edilmesi önerilmektedir. Hâlihazırdaki gidişat biyoçeşitliliğin muhafazasında ekosistem temelli, sürdürülebilir kullanıma dayalı, biyoçeşitlilikten kaynaklanan yararların eşit ve adil paylaşımının dikkate alınmasını gerektirmektedir. $\mathrm{Bu}$ konuda tarım ve madencilik faaliyetlerinin etkilerinin azaltılması, bozulmuş ekosistemlerin restorasyonu, yerel topluluklar için alternatif geçim kaynaklarının oluşturulması, özel sektörle ve muhafaza üzerinde çalışan diğer kuruluşlarla işbirliğinin sağlanması (Anonim 2010).

Doğal alanların yerleşimlerce işgal edilmesi suretiyle ortaya çıkan arazi bozulması ve orman ürünleri, kömür, su ürünleri ve su gibi doğal kaynakların aşırı tüketiminin biyolojik çeşitliliği tehdit eden en önemli faktörler olduğu bildirilmiştir (Anonim, 2016c).

Biyoçeşitlilik bir dizi insan kaynaklı faaliyetlerden olumsuz etkilenmektedir. $\mathrm{Bu}$ faaliyetlerin başında aşırı avlanma, habitat bozulması, yabancı türlerin yaygınlaşması ve işgali, domino etkileri, kirlilik ve iklim değişikliği gelmektedir (Anonim, 2016d).

Petronzio (2015), biyoçeşitlilik üzerinde en önemli 6 tehdidin iklim değişikliği, orman 
tahribatı, habitat kaybı, aşırı kullanım, yayılımcı türler ve kirlenme olduğunu bildirmiştir.

Biyoçeşitliliğin sorunlarına çözüm olmak üzere Şehirali ve Özgen (1987) ile Şehirali ve ark. (2005) genetik kaynaklar konusunda çalışacak kadroların doldurulması ulusal sistem geliştikçe sistemde görev alanlara uygun yetki ve sorumlulukların verilmesi; sistemin çalışmasını sağlamak için iyi eğitilmiş nitelikli insanlar için çekici hale getirilmesi; Hükümet, Enstitüler ve halkın bitki koleksiyonlarının oluşturulması ve saklanmasının önemini daha iyi kavramasıyla, tüm bunların kendiliğinden gerçekleşeceği; insanoğlunun gelecekteki varlığı ve refahı için tarımsal üretimi koruma ve iyileştirmenin tek yolunun genetik çeşitliliğin devamlılığının sağlanması olduğunu bildirmektedirler.

Çakmak (2008) biyolojik çeşitliliği tehdit eden unsurlar olarak aşırı avlanma, istilacı türler, erozyon, çevre sorunları, habitat tahribatı, doğal tehlikeler ve felaketler, genetiği değiştirilmiş organizmalar ve nesli tükenen canlılar olduğunu bildirmiştir. Yazar ayrıca biyolojik çeşitliliğin korunmasının kamu yararına bir durum olduğunu da belirtmiştir.

\section{Materyal ve Yöntem}

Proje bitkisel biyoçeşitlilikle ilişkili tüm kamu ve özel kuruluşları temsilcilerinin, bu kaynakların korunması ve sürdürülebilir kullanımı konularında karşılaştıkları sorunların listelenmesi, bu sorunların ağırlıklarının belirlenmesi, öncelikli sorunlara çözüm önerileri geliştirmesi ve bu önerilerin de derecelendirilmesi yoluyla yapılmıştır. Paydaşların katılımı üç farklı yolla sağlanmıştır.

\section{Üst düzey bürokratlarla görüşmeler}

Türkiye'de bitkisel biyolojik çeşitliliğin korunması ve sürdürülebilir kullanımı konusunda söz sahibi olan Gıda, Tarım ve Hayvancılık Bakanlığı, Orman ve Su İşleri Bakanlığı, Çevre ve Şehircilik Bakanlığı'ndan birer bürokratla görüşerek, BGK ile ilgili sorunların çözümü için önerileri ve varsa bu konularda yapmayı planladıkları yasal ve idari düzenlemeler kayıt edilmiştir.

\section{Sektör temsilcileriyle görüşmeler}

Ülkemizde bitkisel genetik kaynakları doğadan toplayarak veya yetiştirmek yoluyla ham madde olarak yurt içine satan, ihraç eden ve/veya işleyerek mamul ve yarı mamul madde olarak pazarlayan özel sektör kuruluşlarının sorunları ve çözüm önerilerini belirlemek üzere Türkiye'de bu işlerin en yoğun olarak yapıldığı Akdeniz ve Ege bölgelerine giderek sektör temsilcileriyle yüz yüze görüşmeler yapılmıştır.

\section{Grup toplantıları}

Çalışmanın grup toplantıları iki aşamalı olarak gerçekleştirilmiştir. Birinci aşamada tüm paydaşların ülkemizin bitkisel biyolojik çeşitliliğinin sorunları hakkındaki görüş ve düşüncelerini ortaya koydukları iki günlük bir toplantı düzenlenmiş, bunun ardından yine tüm paydaşların ortaya konan sorunlara karşı geliştirilecek çözüm önerilerini görüştükleri iki günlük bir toplantı daha yapılmıştır.

Projenin materyalini yukarıda sözü edilen toplantılar ve görüşmelerde belirlenen görüşler oluşturmuştur. Grup toplantıları sırasında belirlenen sorunlar ve çözüm önerilerinin öncelikleri ve yüzde önem dağılımları Analitik Hiyerarşi Proses (AHP) yöntemiyle hesaplanmıştır. Yöntemin kısa tanımı aşağıda verilmektedir.

\section{Analitik Hiyerarşi Proses}

Analitik Hiyerarşi Proses (AHP), ilk olarak 1968 yılında Myers ve Alpert ikilisi tarafından ortaya atılmış ve 1977 de ise Saaty tarafından bir model olarak geliştirilerek karar verme problemlerinin çözümünde kullanılabilir hale getirilmiştir. AHP, karar hiyerarşisinin tanımlanabilmesi durumunda kullanılan, kararı etkileyen faktörler açısından karar noktalarının yüzde dağılımlarını veren bir karar verme ve tahminleme yöntemi olarak açıklanabilir. AHP bir karar hiyerarşisi üzerinde, önceden tanımlanmış bir karşılaştırma skalası kullanılarak, gerek kararı etkileyen faktörler ve gerekse bu faktörler açısından karar noktalarının önem değerleri açısından, birebir karşılaştırmalara dayanmaktadır. Sonuçta önem farklılıkları, karar noktaları üzerinde yüzde dağılıma dönüşmektedir (Saaty 1990).

Bir karar verme probleminin AHP ile çözümlenebilmesi için gerçekleştirilmesi gereken aşamalar aşağıda tanımlanmıştır. Her bir aşamada, formülasyon ile birlikte ilgili açıklamalar yapılmıştır.

Adım 1: Karar verme problemi tanımlanır

Adım 2: Faktörler arası karşılaştırma matrisi oluşturulur

Adım 3: Faktörlerin yüzde önem dağılımları belirlenir 
Adım 4: Faktör kıyaslamalarındaki tutarlılık Ölçülür

Adım 5: Her bir faktör için karar noktasındaki yüzde önem dağılımları bulunur

Adım 6: Karar noktalarındaki sonuç dağııımı bulunur.

Çalışma sonunda gözden geçirilen faktörlerin ana çözüm aranan sorun üzerindeki ağırıkı etkileri \% değer olarak verilir. AHP yöntemi, projenin ikinci aşamasında her bir konuya getirilen çözüm önerileri için ayrı ayrı uygulanarak her sorun için çözüm önerileri önceliklendirilmiş ve derecelendirilmiş olarak sunulmuştur. AHP uygulaması sübjektif bir değerlendirme yöntemi olarak bitkisel biyolojik çeşitliliğin sorunlarını, bu sorunlar için önerilen çözüm alternatiflerini uzman grubu görüşüne dayanarak önceliklendirme ve faktörlerin önemine nümerik değerler verebilmek açısından kullanılmış ve uygulanmıştır. AHP yönteminde tutarlılık oranının (consistency ratio) \% 10'dan daha küçük olması durumunda yapılan analizin güvenilir olduğu kabul edilir. Yaptığımız çalışmada tüm AHP analizlerinin tutarlılık oranı \% 10'un altındadır. Bu çalışmada sorunlar ve çözüm önerileriyle ilgili hususların belirlenmesinde 9 faktöre kadar AHP analizi yapılmış olmakla beraber burada sadece 7 ve 5 faktör üzerinden yapılan analizlere yer verilmiştir.

\section{Bulgular ve Tartışma}

Üst düzey bürokratlarla görüşmeler sonucu belirlenen hususlar

Sözü edilen üç Bakanlığın ilgili üst düzey bürokratlarıyla yapılan görüşmeler sonucu aşağıda sıralanan hususlar ön plana çıkmıştır:

- Mevzuat hazırlanırken doğa koruma perspektifli gözetilmemektedir,

- Yabancı bilim adamlarıyla ortak çalışma yapmak isteyen Türk araştırıcıların önüne çok fazla engel çıkarılmaktadır,

- Step koruma alanları yoktur, bu yönde yasal düzenleme de eksiktir,

- Bakanlıklar arasında ve aynı bakanlığın farklı kurumları arasında statü çatışması ve çakışması vardır,

- Biyoçeşitlilik envanteri çıkarılması işleri de birden fazla bakanlık elinde olduğundan bu konuda da sorunlar yaşanmaktadır,

- Müstakbel Tabiatı ve Biyolojik
Çeşitliliği Koruma Kanunu, çakışan yetki ve sorumluluklarla ilgili çözüm getirmekten uzaktır,

- Koruma statüsü atanması süreçleri çok uzun ve yorucudur,

- Korunan alanların yönetimi çok başııdır,

- Korunan alan statüleri atanırken sosyal boyut inmal edildiği gibi, sosyal bilim uzmanlarının görüşleri de alınmamaktadır,

- Gıda, Tarım ve Hayvancılık Bakanlığı'nın bitki genetik kaynaklarıyla ilgili düzenleme getiren, 1992 Yönetmeliği geçerliliğini yitirmiştir ve revizyonuna gerek vardır, revize edilirken araştırma izinleri konusu da ele alınmalıdır,

- Nagoya Protokolüne taraf olabilmek için ek mevzuat gereklidir, bu konuda çalışılmalıdır,

- Araştırma izinleri konusu gözden geçirilmelidir,

- Bitki genetik kaynaklarını muhafaza eden enstitülerin alt yapıları eskimiş ve yetersizdir,

- Yerel çeşitlerin halk elinde ıslahı çalışmaları yoktur,

- Yerel çeşitlerin kayıt altına alınmasıyla ilgili çalışma ve kayıt altına almayı kolaylaştırıcı bir yasal düzenlemeye gerek vardır.

Özel sektör temsilcileriyle yapılan görüşmeler sonucu belirlenen hususlar

Antalya, Isparta ve İzmir illerinde toplam 6 özel firmanın yetkilileriyle yapılan görüşmelerde sektör temsilcileri özellikle doğadan toplamalar, yetiştiricilik, maliye ile ilişkiler, üretilen mamul maddenin pazarlanması konularında çok sayıda sorundan söz etmiştir. Sektörün dile getirdiği sorunlar aşağıda özetlenmektedir.

- Doğadan materyal toplayan kırsal kesim nüfusu azalmakta, gençler turizm sektörüne yönelmektedir. $\mathrm{Bu}$ durumda toplayıcı sayısı her geçen gün azalmaktadır,

- Toplayıcılara devlet teşviki yoktur,

- Toplayıcılar kimi yerlerde doğayı ve biyolojik çeşitliliği tahrip ederek toplamaktadır,

- Orman ve Su İşleri Bakanlığı bazı yerlerde keyfi olarak toplamayı yasaklayabilmektedir, 
- $\quad$ Arı üreticileri kimi yerlerde çiçeklenme devresi bitmeden alandan bitki toplanmasını engellemektedir,

- Toplanacak miktarlara kota koyan orman idaresinin kotaları hangi esasa göre koyduğu belirli değildir, bu konuda standart yoktur,

- Piyasadaki tıbbi yağların içeriği konusunda bir standart yoktur, işini doğru yapanla yanlış yapan kurumlar aynı ölçütlere tabidir,

- Resmi kurumlar arasında yetki ve sorumluluk çatışması vardır,

- Endüstriyel yetiştiricilik için alan yoktur, diğer ürünlerin daha kârlı olduğu yerlerde Orman Bakanlığından arazi kiralama imkânı olmamaktadır,

- Tıbbi yağlarla ilgili mevzuat eksiktir,

- Dünyada tıbbi yağlar seyreltik olarak satıldığı halde bizde tam safiyette olması istenmektedir,

- Gıda, Tarım ve Hayvancılık Bakanlığı araştırma kuruluşları ile özel sektör arasında yeterli işbirliği ve bilgi alış verişi yoktur,

- Merdiven altı üretim yapan firmalarla ciddi firmalar aynı terazide tartılmaktadır,

- Ciddi firmalar daha yoğun bir denetleme kıskacı altında tutulmaktadır, denetleme işleri her ilde aynı ciddiyette yapılmamaktadır

- Alo 174 hattına rakip firmalarca yapılan şikâyetler vardır. Bu şikâyetlerin usulsüz olması durumunda şikâyeti yapan kişilere yaptırım uygulanmamaktadır,

- Kimi firmalar uydurma ödüller aldığına dair bir takım işaretler kullanarak haksız rekabete neden olmaktadır,

- Gıda takviyeleri yönetmeliğine intiyaç vardır,

- İnternet üzerinden yapılan satışlarda ilaç algısı yaratılarak haksız rekabet oluşturulmaktadır,

- Dünyada sektörle ilgili gelişmelerin özel sektöre aktarıldığı bir yapıya intiyaç vardır,

- Doğadan toplanan ürünlerin içine toplayıcıların başka bitkileri karıştırmaları sorun yaratmaktadır,

- İhracatta KDV iadesinde sorunlar yaşanmaktadır,
- Toplayıcı kooperatifleri kimi yerlerde keyfi olarak toplamaya izin vermemektedir,

- Yeterince defne bulunamamaktadır,

- Anason ve kimyonda kalite çok düşüktür,

- Tescilli geliştirilmiş çeşit yoktur.

- Kesim izinleri verilirken yükselti farkı gözetilmemekte, tüm alan birden verilmektedir,

- Kültüre alma çalışmaları tüm türlerde yapılmamıştır,

- Üretim materyali, fide, fidan yoktur,

- Ham madde kaynakları yetersizdir,

- Konunun kırsal kalkınmayla olan ilişkisi dikkate alınmamaktadır,

- Orman ve Su İşleri Bakanlığı defne alanlarına sadece orman gözüyle bakmaktadır.

\section{Grup çalışmaları sonuçları}

Gruplar tarafından Türkiye'nin bitkisel biyolojik çeşitliliğine ilişkin sorunlar önce kabaca sıralanmış ve sorun olarak görülen hususlar grup tarafından AHP yöntemi uygulanarak önceliklendirilmiş ve ağırlıkları belirlenmiştir. AHP analizi sonucu Çizelge 1'de belirtilen hususların, Türkiye'deki bitkisel biyolojik çeşitliliğinin en öncelikli 7 sorunu olduğu belirlenmiştir. Çizelgede $\% 5$ 'in altında ağırlığa sahip son iki önceliği alan faktörler elimine edilmiş ve Türkiye'deki bitkisel biyolojik çeşitliliğin en önemli görülen 5 sorunu yeniden değerlendirilip Çizelge 2'de verilmiştir. Çizelge 2 'te de görüldüğü gibi en önemli ilk 5 faktör olarak sıralananlardan arazi bozulması tek başına \% 51.7 gibi önemli bir pay almıştır.

\section{Çözüm önerileri}

Gruplarca belirlenen ve ağırlıkları hesaplanan sorunların her biri, ikinci toplantı boyunca tartışılmış ve her sorun için çözüm önerileri listelenmiş, AHP yöntemiyle önceliklendirilmiş ve ağırlıkları belirlenmiştir.

\section{"Arazi bozulması" sorunu için çözüm önerileri}

Öncelikli sorunların en başında gelen ve kısaca "arazi bozulması" olarak adlandırılan sorun için yapılan değerlendirmeler sonucu, tüm grupların çözüm önerileri olarak ortaya koydukları önlemlerden ağırlıklı olarak öne çıkan ilk 7 önlem Çizelge 3'de sıralanmaktadır. 
Karagöz ve ark. "Türkiye'nin Bitkisel Biyolojik Çeşitliliğinin Korunması ve Sürdürülebilir Kullanımına İlişkin Sorunlar ve Çözüm Önerileri”

Çizelge 1.Sorunlarla ilgili 7 faktör üzerinden yapılan AHP değerlendirmesi Table 1. The AHP evaluation carried out on 7 factors related to the problems

\begin{tabular}{lcc}
\hline Sorunlar & Öncelik sırası & Ağırlığı (\%) \\
\hline Arazi bozulması & 1 & 43.1 \\
Yasal düzenlemelerin / yaptırımların yetersizliği & 2 & 20.6 \\
Plan ve programlarla ilgili sorunlar & 3 & 15.6 \\
Doğadan aşııı bitki hasadı /söküm/aşııı orman kesimi & 4 & 7.5 \\
Kapasite ve yetişmiş insan eksikliği & 5 & 6.4 \\
Yerel çeşitlerin kaybı & 6 & 4.5 \\
Doğal felaketler & 7 & 2.3 \\
\hline
\end{tabular}

Çizelge 2. Sorunlarla ilgili 5 faktör üzerinden yapılan AHP değerlendirmesi Table 2. The AHP evaluation carried out on 5 factors related to the problems

\begin{tabular}{lcc}
\hline Sorunlar & Öncelik sırası & Ağırlığı (\%) \\
\hline Arazi bozulması & 1 & 51.7 \\
Yasal düzenlemelerin / yaptırımların yetersizliği & 2 & 21.2 \\
Plan ve programlarla ilgili sorunlar & 3 & 15.5 \\
Doğadan aşırı bitki hasadı /söküm/aşırı orman kesimi & 4 & 7.1 \\
Kapasite ve yetişmiş insan eksikliği & 5 & 4.5 \\
\hline
\end{tabular}

Çizelge 3. Arazi bozulması sorununu çözmek için belirlenen çözüm önerileri için 7 faktör üzerinden yapılan AHP değerlendirmesi

Table 3. The AHP evaluation carried out on 7 proposals to solve the land degradation problem

\begin{tabular}{lcc}
\hline Çözüm önerileri & $\begin{array}{c}\text { Öncelik } \\
\text { sırası }\end{array}$ & $\begin{array}{c}\text { Ağırlığı } \\
\text { (\%) }\end{array}$ \\
\hline $\begin{array}{l}\text { Amacı dışı alan kullanımını önleyecek yasal düzenlemelerin yapııması } \\
\text { Yatırımlarda biyolojik çeşitliliğin dikkate alınması }\end{array}$ & 1 & 40.5 \\
Kentsel gelişim planlarının yapılmasında biyolojik çeşitliliğin korunmasına ve & 2 & 21.0 \\
$\begin{array}{l}\text { sürdürülebilir kullanılabilirliğine yönelik risklerin dikkate alınması } \\
\text { Kentsel dönüşüm/gelişim planları hazırlanırken ekolojik kentsel tasarım }\end{array}$ & 3 & 13.2 \\
$\begin{array}{l}\text { yaklaşımının belirlenmesi ve hazırlanacak multi disipliner planların merkezi } \\
\text { teşkilat tarafından göz önüne alınması }\end{array}$ & 4 & 11.0 \\
$\begin{array}{l}\text { Farkındalık, halkın bilinçlendirilmesi çalışmalarının yapılması } \\
\text { Kiralamaya uygun orman alanlarında o bölgeye uygun doğal bitkilerin } \\
\text { yetiştirilmesinin tercih edilmesi, }\end{array}$ & 5 & 6.0 \\
Mera ve orman işgallerinin, yapılaşmaların durdurulması & 6 & 4.8 \\
\hline
\end{tabular}

Çizelge 4. Arazi bozulması sorununu çözmek için belirlenen çözüm önerileri için 5 faktör üzerinden yapılan AHP değerlendirmesi

Table 4. The AHP evaluation carried out on 5 proposals to solve the land degradation problem

\begin{tabular}{|c|c|c|}
\hline Çözüm önerileri & Öncelik sırası & Ağırlığı (\%) \\
\hline Amacı dışı alan kullanımını önleyecek yasal düzenlemelerin yapılması & 1 & 49.3 \\
\hline Yatırımlarda biyolojik çeşitliliğin dikkate alınması & 2 & 23.4 \\
\hline $\begin{array}{l}\text { Kentsel gelişim planlarının yapılmasında biyolojik çeşitliliğin korunmasına } \\
\text { ve sürdürülebilir kullanılabilirliğine yönelik risklerin dikkate alınması }\end{array}$ & 3 & 11.4 \\
\hline $\begin{array}{l}\text { Kentsel dönüşüm/gelişim planları hazırlanırken ekolojik kentsel tasarım } \\
\text { yaklaşımının belirlenmesi ve hazırlanacak multi disipliner planların } \\
\text { merkezi teşkilat tarafından göz önüne alınması }\end{array}$ & 4 & 8.7 \\
\hline Farkındalık, halkın bilinçlendirilmesi çalışmalarının yapııması & 5 & 7.2 \\
\hline
\end{tabular}


Çizelge 5. Mevzuat sorununu çözmek için belirlenen çözüm önerileri için 7 faktör üzerinden yapılan AHP değerlendirmesi

Table 5. The AHP evaluation carried out on 7 proposals to solve the problems related to legislative arrangements

\begin{tabular}{lcc}
\hline Çözüm önerileri & Öncelik sırası & Ağırlığı (\%) \\
\hline Araştırma izinleri yerine sürekli yetkiyi belgeleyen kart verilmesi & 1 & 40.4 \\
Toplama izinlerinde yerli araştırmacı lehine düzenlemeler & 2 & 19.7 \\
Araştırma prosedürünün net ve basit hale getirilmesi & 3 & 12.6 \\
Tabiatı ve Biyolojik Çeşitliliği Koruma Kanununun çıkarılması & 4 & 10.2 \\
1992 Yönetmeliğinin güncellenmesi & 5 & 7.5 \\
Biyoçeşitlilik Üst Kurulunun oluşturulması & 6 & 6.1 \\
Yönetmelik hazırlanmasında paydaşların görüşlerinin alınması & 7 & 3.5 \\
\hline
\end{tabular}

Arazi bozulmasının önüne geçmede gruplar tarafından belirlenen liste içinde en etkin 5 önlem olarak Çizelge 4'de yer alan çözüm önerileri ortaya konmuştur.

Çizelge 4'den anlaşılacağı üzere katılımcılar arazilerin amaç dışı kullanımının önüne geçilmesinde başta gelen çözüm olarak yasal düzenlemelerin yapılmasını görmektedir.

\section{"Mevzuat” konusunda çözüm önerileri}

Gruplar tarafından bitkisel biyolojik çeşitliliğimizin en önemli ikinci sorunu olarak belirlenen "yürürlükteki mevzuatın eksikliği, yetersizliği, uygulanmasında yaşanan güçlükler ve güncelliğini yitirmiş olması" (kısaca "mevzuat") konusunda en fazla yakınma, araştırıcılarca arazi çalışmaları sırasında her yıl, her yöre için farklı Bakanlıklardan alınması gereken ve kısaca "araştırma izinleri" olarak ifade edilen konuda olmuştur. Bu konuya ve aynı başlık altında dile getirilen diğer çözüm önerileri Çizelge 5'de sıralanmaktadır. Mevzuat konusuna getirilen çözüm önerilerinin 5 adede indirilmesi durumunda listede araştırma izinleri dışında sadece Biyoçeşitlilik Üst Kurulu ve Biyoçeşitlilik Enstitüsü kurulması ile Tabiatı ve Biyolojik Çeşitliliği Koruma Kanununun çıkarılması ile 1992 Yönetmeliğinin güncellenmesi konuları kalmıştır (Çizelge 6).

\section{"Plan ve programlar" için çözüm önerileri}

Grup tarafından üçüncü önemli sorun olarak belirlenen ve kısaca "plan ve programlar" olarak adlandırılan "doğal kaynak koruma ve sürdürülebilir kullanımına yönelik yönetim ve planlamayla ilgili sorunlar" ile ilgili olarak Ulusal Biyoçeşitlilik Stratejisi ve Eylem Planı (UBSEP) konusuna çok atıfta bulunulmuştur. Öncelikli olarak önerilen ilk 7 konu Çizelge 7 'de verilmektedir.

Çözüm önerilerinin sayısı 5'e düşürülünce en önemli faktör olarak \%46.6 ile plan ve programların UBSEP'e uygun olması faktörü öne çıkmışıır (Çizelge 8).

"Doğadan aşırı toplama" için çözüm önerileri

Dördüncü en önemli sorun olarak belirlenen "doğadan aşırı ve usulüne uygun olmayan toplama (kısaca "doğadan aşırı toplama") sorununa çok farklı konularda çözüm önerileri ortaya konmuştur.

Bu konuda yapılan AHP analizinde öncelikli çözüm önerisi olarak Çizelge 9'daki hususlar ön plana çıkmıştır.

Doğadan aşırı toplama sorunu için belirlenen çözüm önerilerinden son ikisi çıkarılarak yapılan AHP analizi sonucu Çizelge 10'da verilmektedir.

Görüleceği üzere grup yarıyı aşkın bir şekilde öncelikli çözüm önerisi olarak soğanlı bitkiler dışındaki ürünlerde de her yıl toplama kotaları belirlenmesinden yanadır.

\section{Kurumsal kapasite" konusundaki sorunlar için çözüm önerileri}

Kısaca "kurumsal kapasite" olarak nitelenen konu başlığı altında ilk 7 sırada yer alan çözüm

Çizelge 6. Mevzuat sorununu çözmek için belirlenen çözüm önerileri için 5 faktör üzerinden yapılan AHP değerlendirmesi

Table 6. The AHP evaluation carried out on 5 proposals to solve the problems related to legislative arrangements

\begin{tabular}{lcc}
\hline Çözüm önerileri & Öncelik sırası & Ağırlı̆̆ı (\%) \\
\hline Araştırma izinleri yerine sürekli yetkiyi belgeleyen kart verilmesi & 1 & 47.3 \\
Toplama izinlerinde yerli araştırmacı lehine düzenlemeler & 2 & 20.6 \\
Araştırma prosedürünün net ve basit hale getirilmesi & 3 & 13.3 \\
Tabiatı ve Biyolojik Çeşitliliği Koruma Kanununun çıkarılması & 4 & 9.4 \\
1992 Yönetmeliğinin güncellenmesi & 5 & 9.4 \\
\hline
\end{tabular}


Karagöz ve ark. "Türkiye’nin Bitkisel Biyolojik Çeşitliliğinin Korunması ve Sürdürülebilir Kullanımına İlişkin Sorunlar ve Çözüm Önerileri”

Çizelge 7. Plan ve programlar ile ilgili sorununu çözmek için belirlenen çözüm önerileri için 7 faktör üzerinden yapılan AHP değerlendirmesi

Table 7. The AHP evaluation carried out on 7 proposals to solve problems related to plans and programs

\begin{tabular}{lcc}
\multicolumn{1}{c}{ Çözüm önerileri } & $\begin{array}{c}\text { Öncelik } \\
\text { sırası }\end{array}$ & $\begin{array}{c}\text { Ağırlığı } \\
\text { (\%) }\end{array}$ \\
\hline Plan ve projelerin UBSEP'e uygun hazırlanması & 1 & 38.1 \\
Plan ve projelerde kaynakların etkin kullanılması & 2 & 17.6 \\
Plan ve programlar hazırlanırken ekosistem hizmetlerinin dikkate alınması & 3 & 17.6 \\
UBSEP'in revize edilmesi & 4 & 9.4 \\
Plan ve program uygulamalarında yetki ve sorumluluklar belirlenmesi & 5 & 6.3 \\
Envanter projesi sonucunda özelleşecek ikincil projelerin tasarlanması & 6 & 5.5 \\
UBSEP ile diğer sektörlerin gelişme planları ile uyumlu olması & 7 & 5.5 \\
\hline
\end{tabular}

Çizelge 8. Plan ve programlar ile ilgili sorununu çözmek için belirlenen çözüm önerileri için 7 faktör üzerinden yapılan AHP değerlendirmesi

Table 8. The AHP evaluation carried out on 7 proposals to solve problems related to plans and programs

\begin{tabular}{lcc}
\hline Çözüm önerileri & $\begin{array}{c}\text { Öncelik } \\
\text { sırası }\end{array}$ & $\begin{array}{c}\text { Ağırlığı } \\
(\%)\end{array}$ \\
\hline Plan ve projelerin UBSEP'e uygun olarak hazırlanması & 1 & 46.6 \\
Plan ve projelerde kaynakların etkin kullanılması & 2 & 19.4 \\
Plan ve programlar hazırlanırken ekosistem hizmetlerinin dikkate alınması & 3 & 19.4 \\
UBSEP'in revize edilmesi & 4 & 7.3 \\
Plan ve program uygulamalarında yetki ve sorumluluklar belirlenmesi & 5 & 7.3 \\
\hline
\end{tabular}

Çizelge 9. Doğadan aşırı toplama ile ilgili sorununu çözmek için belirlenen çözüm önerileri için 7 faktör üzerinden yapılan AHP değerlendirmesi

Table 9. The AHP evaluation carried out on 7 proposals to solve the problems related to over harvesting from nature

\begin{tabular}{lcc}
\hline Çözüm önerileri & $\begin{array}{c}\text { Öncelik } \\
\text { sırası }\end{array}$ & $\begin{array}{c}\text { Ağırlığı } \\
(\%)\end{array}$ \\
\hline Kurumlar arası iş birliği yapılması & 1 & 22.1 \\
BGK araştırma enstitülerinin kurulması & 2 & 22.1 \\
Kurumların bölgelerindeki ihtiyaca göre özelleşme / uzmanlaşmaya gitmesi & 3 & 22.1 \\
Tüm enstitülerde yeterli uzman personel ve ara elemanı istihdam edilmesi & 4 & 16.1 \\
Personel altyapısının eğitimle güçlendirilmesi & 5 & 10.1 \\
Tüm enstitülerde BÇ bölümlerinin açılması & 6 & 5.1 \\
Üniversitelerde konu hakkında master/doktora yapan araştırmacıların & 7 & 3.3 \\
bakanlıklarda istihdamına öncelik verilmesi & 7 & 3 \\
\hline
\end{tabular}

Çizelge 10. Doğadan aşırı toplama ile ilgili sorununu çözmek için belirlenen çözüm önerileri için 5 faktör üzerinden yapılan AHP değerlendirmesi

Table 10. The AHP evaluation carried out on 5 proposals to solve the problems related to over harvesting from nature

\begin{tabular}{lcc}
\hline Çözüm önerileri & Öncelik sırası & A ğırı̆̆ı (\%) \\
\hline Soğanlı bitkiler dışında da toplama kotaları listesi hazıılanması, & 1 & 50.4 \\
Doğadan toplanan türlerde kültüre alma çalışmaları yapılması, & 2 & 24.5 \\
Tıbbi aromatik bitkilerde tescilli çeşitler geliştirilmesi, & 3 & 10.2 \\
Kırmızı listenin güncellenmesi, & 4 & 10.2 \\
Toplayıcıların sertifikalandırılması, & 5 & 4.6 \\
\hline
\end{tabular}

önerileri ve ağırlıkları Çizelge 11 'de yer konusunda grubun hazırladığı çözüm almaktadır. Çizelge 11'de görüldüğü üzere ilk 3 önerilerinden öne çıkan 7 tanesi Çizelge 13'de sırayı alan çözüm önerileri eşit ağırlığa sahiptir. Analizin bir de 5 faktör üzerinden yapılması durumunda yine ilk 3 sırayı alan öneriler eşit ağırlıkta bulunmuştur (Çizelge 12).

"Yerel çeşitler" konusunda çözüm önerileri

Kısaca "yerel çeşitler" olarak söz edeceğimiz yerel çeşitler ve geleneksel bilginin kaybı verilmektedir.

Çizelge 13 'de görüldüğü üzere yerel çeşitlerin korunmasında devletin destek vermesi talebi yarıdan daha büyük bir ağırlığa sahiptir. Son iki faktörün çıkarılmasıyla faktör sayısı 5'e düşürülmüş ve yapılan AHP analizi sonuçları Çizelge 14 'de verilmiştir. 
Çizelge 11. Kurumsal kapasitelerle ilgili sorununu çözmek için belirlenen çözüm önerileri için 7 faktör üzerinden yapılan AHP değerlendirmesi

Table 11. The AHP evaluation carried out on 7 proposals to solve problems related to institutional capacities

Çözüm önerileri

Yerel çeşitlerin üretimine yönelik devlet desteği verilmesi

uncelık Agırıgı

Yerel bilgilerin kayıt altına alınması

SIrası (\%)

Yerel çeşit envanteri çıkarılması

Tohumculuk Kanunu revize edilerek yerel çeşitler önündeki engellerin kaldırılması

1

Yerel çeşitlerin in-situ korumaya alınması

Etnobotanik veri tabanının oluşturulması

Çizelge 12. Kurumsal kapasitelerle ilgili sorununu çözmek için belirlenen çözüm önerileri için 5 faktör üzerinden yapılan AHP değerlendirmesi

Table 12. The AHP evaluation carried out on 5 proposals to solve problems related to institutional capacities

\begin{tabular}{lcc}
\hline Çözüm önerileri & $\begin{array}{c}\text { Öncelik } \\
\text { sırası }\end{array}$ & $\begin{array}{c}\text { Ağırlığı } \\
\mathbf{( \% )}\end{array}$ \\
\hline Yerel çeşitlerin üretimine yönelik devlet desteği verilmesi & 1 & 52.5 \\
Yerel bilgilerin kayıt altına alınması & 2 & 23.6 \\
Yerel çeşit envanteri çıkarııması & 3 & 10.0 \\
Tohumculuk Kanunu revize edilerek yerel çeşitler önündeki engellerin kaldırılması & 4 & 9.4 \\
Yerel çeşitlerin in-situ korumaya alınması & 5 & 4.5 \\
\hline
\end{tabular}

Çizelge 13. Yerel çeşitler ve geleneksel bilgi ilgili sorununu çözmek için belirlenen çözüm önerileri için 7 faktör üzerinden yapılan AHP değerlendirmesi

Table 13. The AHP evaluation carried out on 7 proposals to solve problems related to landraces and traditional knowledge

\begin{tabular}{lcc}
\hline Çözüm önerileri & Öncelik sırası & Ă̆ırlığı (\%) \\
\hline Muhafaza edilen materyalin emniyet yedeklenmesinin yapılması & 1 & 53.5 \\
Acil durum eylem planları ve erken uyarı sistemlerinin geliştirilmesi & 2 & 19.3 \\
Felaketlerin BÇ teşviki yoluyla engellenmesi, & 3 & 16.6 \\
Orman yönetim planlarının hazırlanması ve doğru uygulanması, & 4 & 7.2 \\
Tohumla üretilmesinde zorluklar olan türlerde DNA ve krayo & 5 & 3.5 \\
muhafaza uygulanması & 5 \\
\hline
\end{tabular}

Çizelge 14. Yerel çeşitler ve geleneksel bilgi sorununu çözmek için belirlenen çözüm önerileri için 5 faktör üzerinden yapılan AHP değerlendirmesi

Table 14. The AHP evaluation carried out on 5 proposals to solve problems related to landraces and traditional knowledge

\begin{tabular}{lcc}
\hline Çözüm önerileri & $\begin{array}{c}\text { Öncelik } \\
\text { sırası }\end{array}$ & $\begin{array}{c}\text { Ağırlığı } \\
(\%)\end{array}$ \\
\hline Yerel çeşitlerin üretimine yönelik devlet desteği verilmesi & 1 & 52.5 \\
Yerel bilgilerin kayıt altına alınması & 2 & 23.6 \\
Yerel çeşit envanteri çıkarılması & 3 & 10.0 \\
Tohumculuk Kanunu revize edilerek yerel çeşitler önündeki engellerin kaldırılması & 4 & 9.4 \\
Yerel çeşitlerin in-situ korumaya alınması & 5 & 4.5 \\
\hline
\end{tabular}

Çizelge 15. Doğal felaketlerle ilgili sorununu çözmek için belirlenen çözüm önerileri AHP değerlendirmesi Table 15. The AHP evaluation carried out on the proposals to solve problems related to natural disasters

\begin{tabular}{lcc}
\hline Çözüm önerileri & Öncelik sırası & A ğırlığı (\%) \\
\hline Muhafaza edilen materyalin emniyet yedeklenmesinin yapılması & 1 & 53.5 \\
Acil durum eylem planları ve erken uyarı sistemlerinin geliştirilmesi & 2 & 19.3 \\
Felaketlerin BÇ teşviki yoluyla engellenmesi, & 3 & 16.6 \\
Orman yönetim planlarının hazırlanması ve doğru uygulanması, & 4 & 7.2 \\
Tohumla üretilmesinde zorluklar olan türlerde DNA ve krayo & 5 & 3.5 \\
muhafaza uygulanması & & \\
\hline
\end{tabular}




\section{Doğal felaketler" konusunda çözüm önerileri}

Gruptan doğal felaketlerin bitkisel biyolojik çeşitlilik üzerindeki olumsuz etkilerinin azaltılması için sadece 5 faktör listelenebilmiştir. Bu nedenle AHP hesaplaması sadece 5 faktör üzerine yapılmış olup Çizelge 15 'de verilmektedir

Doğal felaketler karşısında bitkisel biyolojik çeşitliliğin zarar görmemesi açısından emniyet yedeklerinin oluşturulması konusu öncelik kazanmıştır.

\section{Sonuç}

Çalışma ile (a) Türkiye'deki bitkisel biyolojik çeşitliliğin sorunları belirlenmiş, (b) Türkiye'deki bitkisel biyolojik çeşitliliğin sorunlarını çözmek için öneriler geliştirilmiştir. Proje sonunda Türkiye'deki bitkisel biyolojik çeşitliliğin öncelikli sorunları olarak arazi bozulması konusu ilk sırada yer almıştır. Bu konu her üç Rio sözleşmesinde de benzer şekilde değerlendirilmektedir. Biyolojik Çeşitlilik Sözleşmesinde biyolojik çeşitlilik tanımı içinde "habitat çeşitliliği" de yer almaktadır (Anonim 2016e). Bununla yanında Çölleşmeyle Mücadele Sözleşmesi'nin ana konusu arazi bozunumu olup (Anonim 2016f), İklim Değişikliği Çerçeve Sözleşmesinde de iklim değişikliğiyle arazi bozulması arasında ilişki kurulmuştur (Anonim 2016g). Sorunlar arasında yer alan yasal düzenlemelerin yetersizliği ve etkin olmayışı, plan ve programlarla ilgili konular kurumsal ve bireysel kapasitelerin yetersizliği konuları da UBSEP'te (Anonim 2007) aynı şekilde yer almaktadır.

Aichi Hedefleri (Anonim 2016b) içinde yer alan Stratejik Amaçlardan ilki biyoçeşitliliği hükümet ve toplum içinde hâkim anlayış haline getirmektir. Bunu gerçekleştirmek için eğitim ve bilinçlenme çalışmalarının büyük önemi vardır. $\mathrm{Bu}$ çalışmada da halkın bilinçlendirilmesi konusu en önemli sorun olarak görülen arazi bozulmasına karşı geliştirilen çözüm önerilerinden biri olmuştur. Buna karşılık son dönemlerde giderek daha fazla ilgi çeken bir kavram olan biyoçeşitliliğin sağlamış olduğu ekosistem hizmetleri konusu toplantılar boyunca görüşülmüş olmakla beraber, ekosistem hizmetlerinin devamlılığı veya geliştirilmesi konularında çizelgelere giren bir husus olmamıştır. Benzer şekilde çalışmalar boyunca GDO'nun ve yabancı yayılımcı türlerin olası olumsuz etkilerinden söz edilmiş olmakla beraber tehditler arasında GDO konusu 9. sırada yer almıştır, yabancı yayılımcı türler konusu önem sıralamasında ilk 9 içine girmemiştir. Aslen Türkiye'de yürürlükte olan 5977 sayılı Biyogüvenlik Kanunu (Anonim 2016h) Türkiye'de genetiği değiştirilmiş canlıların üretilmesine izin vermemektedir.

Türkiye'de bir yandan doğa korumayla ilgili yasaların etkisiz ve caydırıcı olmaktan söz edilirken, diğer yandan da en önemli sorun olarak gösterilen "mevzuat" konusunda farklı anlamlarda yorumlar getirilmiştir. Tüm doğa koruma işlerini adeta tek bir düzenlemeyle yerine getirmesi istenen ve üzerine çok fazla görev bindirilen Tabiatı ve Biyolojik Çeşitliliği Koruma Kanununun bir an önce çıkarılması gerektiğinden sıkça söz edilmiştir. Ayrıca katılımcıların mevzuat başı̆̆ı altında diğer bir beklentisi de yapılacak düzenleme ile araştırma çalışmalarını kolaylaştırıcı yönde bir "araştırma izinleri" yasal düzenlemesi beklentisi güçlü şekilde dile getirilmiştir. Diğer bir beklenti de UBSEP'in revize edilmesi olmuştur.

Doğadan aşırı hasadın bitkisel BÇ üzerine olumsuz etkilerinden birçok çalışmada söz edilmektedir (Anonim 2007; Çakmak 2008; Karagöz ve ark., 2010). Çalışmamızda da bu duruma işaret edilmiş olup çözüm önerileri olarak doğa üzerine baskıların azaltılması için kültüre alma çalışmaları, toplayıcıların eğitimi ve sertifikalandırılması, çeşit geliştirilmesi gibi öneriler ön plana çıkmışır.

Kurumsal kapasitelerin yetersizliği konusu UBSEP'te olduğu gibi bu çalışmada da altı çizilen konulardandır. Bu konuda kurumlar arası işbirliği yanında BGK araştırma kuruluşlarının daha yaygınlaştırılması önerilmiştir. Kurumsal kapasitelerle de bağlantılı olan yerel çeşitlerin sürekliliğinin sağlanması konusunda yasal düzenleme (Tohumculuk Kanununun revizyonu) ve üretim desteği yanında yerel çeşitlerin kayıt altına alınması çalışmalarına yasal ve teknik zemin hazırlanması da istenmiştir.

\section{Teşekkür}

Bu çalışma TAGEM 14 AR-GE 56 numaralı proje kapsamında TAGEM tarafından desteklenmiştir. Proje boyunca katkıları için TAGEM Tarım Ekonomisi Araştırmaları Dairesi Başkanlığına, Tarla Bitkileri Araştırmaları Daire Başkanlığına, Biyoçeşitlilik ve Genetik Kaynaklar Araştırmaları Koordinatörü Dr. Esin Dilbirliği'ne, Tarla Bitkileri Merkez Araştırma Enstitüsü Biyoçeşitlilik ve Genetik Kaynaklar 
Bölümü teknik elemanlarına, Batı Akdeniz Tarımsal Araştırma Enstitüsünden Dr. Saadet Tuğrul Ay'a ve çalışmaya katkıda bulunan tüm katılımcılara teşekkür ederiz.

\section{Kaynaklar}

Anonim, 2007. Ulusal Biyolojik Çeşitlilik Stratejisi ve Eylem Planı, T.C. Çevre ve Orman Bakanlığı, Doğa Koruma ve Milli Parklar Genel Müdürlüğü Doğa Koruma Dairesi Başkanlığı

Anonim, 2010. http://www.unep.org/delc/Portals/119/State\%20of\%20biodiversity\%20i n \% 20 Africa.pdf (Erişim tarihi: 25.04.2016)

Anonim, 2015. http://iucn.org/news_homepage/all_news_by_region /news_ from_ europe/?21358/EU-State-of-Nature-Reportpoints-to-continued-loss-of-biodiversity-butsuccess-of-Natura-2000 (Erişim tarihi: 25.04.2016)

Anonim, 2016a. http://herbaryum.tagem.-gov.tr/ (Erişim tarihi: 25.04.2016)

Anonim,2016b. https://www.cbd.int/sp/targets/ (Erişim tarihi: 25.04.2016)

Anonim, 2016c. Major threats to biodiversity. http://www.globalchange.umich.edu/ globalchange2/current/lectures/biodiversity/bi odiversity.htm (Erişim tarihi: 21.01.2016)

Anonim, 2016d. https://www.khanacademy.org/partner-content/CAS-biodiversity/why-isbiodiversity-threatened/local-threats-tobiodiversity/ (Erişim tarihi: 25.04.2016)

Anonim, 2016e. https://www.cbd.int/ (Erişim tarihi: 25.04.2016)

Anonim, 2016f. http://www.unccd.int/en/Pages/default.aspx (Erişim tarihi: 25.04.2016)

Anonim, 2016g. http://unfccc.int/2860.php (Erişim tarihi: 25.04.2016)

Anonim, 2016h. http://www.resmigazete.gov.tr/eskiler/2010/03/20100326-7.htm (Erişim tarihi: 25.04.2016)

Çakmak M., 2008. Conservation of Biological Diversity by Law and Public Interest, AÜHFD, 133-166

Gökgöl M., 1935. Türkiye'nin Buğdayları. Tom I. 436 $\mathrm{s}$, İstanbul

Gökgöl M., 1939. Türkiye'nin Buğdayları. Tom II. 955 $\mathrm{s}$, İstanbul

Gökgöl M. ve Taşan R., 1978. Yeşilköy Zirai Araştırma Enstitüsü'nün (Marmara-Trakya Bölge Zirai Araştırma Enstitüsü) 50. Yılı, 1926-1976. İstanbul
Güner A., Aslan S., Ekim T., Vural M. ve Babaç M.T., 2012. Türkiye Bitkileri Listesi (Damarlı Bitkiler). Nezahat Gökyiğit Botanik Bahçesi ve Flora Araştırmaları Derneği Yayını, 1290 s. İstanbul

Henle K., Alard D., Clitherow J., Cobb P., Fribank L., Kull T., McCracken, D., Moritz R.F.A., Niemela J., Rebenej M., Walcher D., Watt A., Young J., 2008. Identifying and managing the conflicts between agriculture and biodiversity conservation in Europe-A review. Agriculture, Ecosystems and Environment 124: 60-71

Hood L., 2010. Biodiversity: Facts and Figures. http://www.scidev.net/global/biodiversity /feature/biodiversity-facts-and-figures-1.html

Karagöz A., Zencirci N., Tan A., Taşkın T., Köksel H., Sürek M., Toker C. ve Özbek K., 2010. Bitki Genetik Kaynaklarının Korunması ve Kullanımı. Türkiye Ziraat Mühendisliği VII. Teknik Kongresi. Bildiriler (I): 11-15 Ocak, Ankara, s. 155-177

Maes J., Paracchini M .L., Zuliana G., Dunbara M. B., Alkamade R., 2012. Synergies and tradeoffs between ecosystem service supply, biodiversity, and habitat conservation status in Europe. Biological Conservation 155: 1-12

Petronzio . M., 2015. 5 major threats to biodiversity, and how we can have curb them. http://mashable.com/2015/05/23/biodiversitythreats/

Saaty T. L., 1990. How to make a decision: The Analytic Hierarchy Process. Desicion making by the analytic hierarchy proces: Theory and applications, European Journal of Operational Research, 48(1): 9-26

Şehirali S. ve Özgen M., 1987. Bitki genetik kaynakları. Ankara Üniv. Ziraat Fak. Yayınları No: 1020. Ders Kitabı: 294, Ankara

Şehirali S., Özgen M., Karagöz A., Sürek M., Adak S., Güvenç I., Tan A., Burak M., Kaymak H.Ç., Kenar D., 2005. Bitki genetik kaynaklarının korunma ve kullanımı. TMMOB Ziraat Mühendisleri Odası VI. Teknik Kongresi. Cilt 1. Kozan Ofset, Ankara. 253- 273.

Young J, Watt A., Norwick P., Alard D., Clitherow J., Henle K., Johnson R., Laczko E., McCracken, D., Matouch S., Niemela J. and Richards C., 2005. Towards sustainable land use: identifying and managing the conflicts between human activities and biodiversity conservation in Europe. Biodiversity and Conservation 14: s: 1641-1661 